\title{
Implementasi Video Teks Narasi untuk Meningkatkan Keterampilan Menulis Teks Narasi Siswa Kelas V
}

\author{
Salsabillah Adlani*, Ratna Trieka Agustina, Muchtar \\ Universitas Negeri Malang, Jl. Semarang No. 5 Malang, Jawa Timur, Indonesia \\ *Penulis korespondensi, Surel: adlanisalsabillah@gmail.com
}

Paper received: 2-1-2021; revised: 23-1-2021; accepted: 30-1-2021

\begin{abstract}
This research aimed: (1) the application of narrative text video media could increase learning activities in writing narrative text of the fifth grade students of SDN Sukolilo Jabung, (2) the application of learning media text video could increase the students skill in writing narrative text of the fifth grade students of SDN Sukolilo Jabung. This research described classroom activities using a qualitative approach. The result of this research was that the ability of writing Indonesian paragraphs rose from the average 71,2 with the classical completeness 73 percent in the cycle 1 to 84,63 with the classical completeness 94 percent in the cycle 2. It showed that the application of narrative text video media model could enhance the skill of writing narrative text.
\end{abstract}

Keywords: writing an Indonesian paragraph; narration text video; $5^{\text {th }}$ grade students

\begin{abstract}
Abstrak
Penelitian ini bertujuan: (1) penerapan media video teks narasi dapat meningkatkan kegiatan pembelajaran menulis teks narasi pada siswa kelas V SDN Sukolilo Jabung, (2) penerapan media pembelajaran video teks dapat meningkatkan keterampilan menulis teks narasi pada siswa kelas $\mathrm{V}$ SDN Sukolilo Jabung. Penelitian ini merupakan penelitian tindakan kelas dengan pendekatan kualitatif deskriptif. Berdasarkan hasil penelitian, keterampilan menulis paragraf Bahasa Indonesia meningkat dari nilai rata-rata 71,2 dengan ketuntasan klasikal 73 persen pada siklus I menjadi 84,63 dengan ketuntasan klasikal 94 persen pada siklus II. Hal ini menunjukkan bahwa penerapan model media video teks narasi dapat meningkatkan keterampilan menulis teks narasi.
\end{abstract}

Kata kunci: menulis paragraf Bahasa Indonesia; media video teks narasi; siswa Kelas V

\section{Pendahuluan}

Bahasa Indonesia adalah sarana untuk menyebarkan informasi yang dilakukan oleh anggota masyarakat dalam berinteraksi, bersosialisasi, bekerjasama (Pusat Bahasa Kemdikbud, 2016). Dengan demikian bahasa sangat penting bagi manusia untuk berkomunikasi tanpa bahasa manusia tidak dapat berinteraksi. Bahasa mempunyai kedudukan fundamental dalam perkembangan daya pikir dalam kemasyarakatan, emosional siswa dalam pengampu penguasaan kemampuan akademis.

Pembelajaran bahasa indonesia bertujuan dengan meningkatkan kemampuan siswa dalam keempat aspek keterampilan yang saling terkait. Diantaranya keterampilan dalam menyimak, membaca, berbicara dan menulis. Dalam bahasa indonesia memiliki empat aspek keterampilan yang saling berkaitan, antara lain keterampilan menyimak, berbicara, membaca dan menulis. (Depdiknas, 2008). Tarigan, (2013) menyatakan bahwa empat keterampilan dalam berbahasa terdiri dari empat bagian, ialah keterampilan menyimak (listening skills); keterampilan berbicara (speaking skills); keterampilan membaca (reading skills); dan keterampilan menulis (writing skills); Keempat aspek keterampilan dalam berbahasa saling memiliki keterkaitan sehingga berhubungan dengan erat (Aisyah \& Nur Dina, 2013) 
Keterampilan menulis merupakan salah satu aktivitas kompleks yang merupakan bagian dari sifat dalam aktivitas pembelajaran. Keterampilan menulis memiliki beberapa aktivitas yang memerlukan pola pikir yang sistematis dan terstruktur serta pemahaman dalam pemilihan kosa kata, kalimat efektif, ejaan dan tanda baca untuk memaparkan pikiran, ide, informasi, pengetahuan dan pengalaman bentuk bahasa tulis (Yunus, 2014). Hanya orang-orang yang memiliki kemampuan dalam menyusun pikiran dan dapat mengatakannya dengan jelas, serta dapat memilih pemakaian kata-kata dan struktur kalimat yang baik dan benar dapat mengimplementasikan keterampilan menulis sehingga dapat menggunakan keterampilannya sebagai sarana untuk berbagi informasi, merekam ataupun mencatat, meyakinkan bahkan mempengaruhi (Tarigan, 2013).

Pembelajaran menulis teks narasi pada siswa kelas V SD melingkupi menulis deskripsi, surat pribadi dan resmi, narasi persuasi dan eksposisi, puisi, pantun, dan cerpen. Dengan demikian, keterampilan menulis adalah keterampilan yang harus dikuasai siswa dalam pembelajaran menulis narasi. (Zainurrahman, 2016) menggemukkan menulis teks narasi merupakan tulisan yang mengisahkan sebuah peristiwa yang didalamnya terkandung tokoh, alur, latar dan tema cerita. Narasi bertujuan untuk mengkomunikasikan hubungan kejadian atau pengalaman individu dari suatu kurun waktu ke waktu lainnya. Keterampilan ini penting dikuasai siswa sebagai sarana siswa mengkomunikasikan rangkaian peristiwa yang dialami dalam kehidupan sehari-harinya secara rinci dan berurutan.

Dari hasil wawancara yang dilakukan oleh peneliti kepada guru kelas V SDN Sukolilo diperoleh permasalahan yang dialami oleh guru. Rendahnya keterampilan siswa menulis teks narasi pada mata pelajaran bahasa indonesia materi narasi sejarah. Guru menjelaskan bahwa siswa kesulitan dalam menyajikan runtutan peristiwa dalam teks narasi sejarah. Dalam aktivitas pembelajaran berlangsung guru sering kali melaksanakan pembelajaran dengan cara tradisional dengan menggunakan metode ceramah, guru belum menggunakan media tertentu selama pembelajaran berlangsung. Guru hanya mengandalkan buku siswa sebagai media pembelajaran, dan memposisikan guru sebagai sumber materi. Maka demikian, diperlukan sebuah aktivitas yang dapat meningkatkan keterampilan menulis siswa dalam menulis teks narasi.

Berdasarkan hasil temuan penelitian pada siklus I dan II dapat disimpulkan bahwa video teks narasi dapat meningkatkan keterampilan menulis teks narasi pada siswa kelas V SDN Sukolilo Kabupaten Malang. Dapat dilihat dari peningkatan penilaian hasil menulis teks narasi di setiap siklusnya. Menunjukkan siswa lebih mengerti dan memahami dalam menulis teks narasi . Keberanian dan antusias untuk membacakan hasil teks narasi nya di depan kelas sangat baik, karena tanpa guru menunjuk siswa berani mengacungkan tangan untuk tampil membacakan hasil teks narasi nya. Selain itu, ketuntasan belajar juga sudah dicapai oleh seluruh siswa. Penerapan video narasi sejarah dalam pembelajaran dapat meningkatkan keterampilan siswa menulis teks narasi yang didalamnya terdapat peningkatan keterampilan siswa dalam menentukan urutan peristiwa, tokoh dalam peristiwa, ketepatan ejaan, kepaduan kata/kalimat, ketepatan penggunaan bahasa dan huruf kapital, serta penggunaan tanda baca.

\section{Metode}

Peneliti menggunakan analisis data secara deskriptif kualitatif. Dalam bukunya, (Akbar, 2010) memperjelas bahwa dalam prosedur penelitian tindakan kelas pada umumnya teknik pengumpulan datanya terbagi menjadi 3 yaitu, teknik observasi, tes dan dokumentasi dengan 
peneliti sebagai instrumen dengan bantuan pedoman penelitian dengan hasil data yang dideskripsikan.

Analisis data dilakukan ketika semua data telah terkumpul. Arikunto (2013) menyatakan bahwa secara garis besar , analisis data memiliki tiga tahap. Secara garis besar analisis data terbagi menjadi tahap persiapan, tahap tabulasi dan tahap penerapan data sesuai dengan pendekatan penelitian Prosedur pada penelitian tindakan kelas ini yakni: (1) perencanaan tindakan, (2) pelaksanaan tindakan kelas, (3) pengamatan, (4) refleksi dalam setiap siklusnya.

Tahap perencanaan awal merupakan kegiatan pengumpulan data sebagai acuan untuk menentukan tindakan yang tepat dalam pelaksanaan penelitian yang dilengkapi dengan kegiatan observasi dan wawancara. Langkah berikutnya yang dilakukan yaitu menyiapkan perangkat pembelajaran berupa RPP. Kemudian dilanjutkan menyiapkan instrumen penilaian tes dan non tes, serta menyiapkan alat untuk dokumentasi. Instrumen tes berupa tes menulis paragraf serta instrumen penilaian tes menulis. dan instrumen non tes berupa lembar panduan observasi aktivitas guru dan siswa.

Kedua, tahap pelaksanaan yaitu tahap dari perencanaan yang telah dibuat. Adapun pelaksanaan yang dilakukan oleh guru kelas yaitu dua kali pertemuan pada setiap siklus dengan menerapkan media video teks narasi pada RPP setiap pembelajaran. Ketiga, tahap pengamatan. Kegiatan ini dilakukan oleh peneliti dan teman sejawat yang bertugas sebagai penilaian aktivitas guru dan aktivitas siswa selama kegiatan berlangsung. Berdasarkan hasil observasi dan tes, maka siklus berikutnya dapat dilaksanakan.

Keempat, tahap refleksi. Kegiatan ini merupakan tahap mengungkapkan kembali pengalaman selama terlibat secara langsung dalam proses pembelajaran. Baik mengenai hal yang telah terlaksana maupun belum terlaksana saat pelaksanaan penelitian berlangsung. Selama penelitian dilaksanakan, hasilnya akan dianalisis dan dikaji kegagalan serta keberhasilannya. Apabila hasil data yang telah dianalisis masih mengalami kekurangan, maka hasil analisis dari siklus I akan direfleksikan untuk menentukan tindakan pelaksanaan pembelajaran untuk siklus II agar tujuan dapat tercapai dengan optimal.

\section{Hasil dan Pembahasan}

Berdasarkan penelitian yang dilaksanakan secara menyeluruh pada siklus I dan siklus II pada siswa kelas Kelas V SDN Sukolilo Jabung melalui penerapan media video teks narasi, terjadi peningkatan aktivitas guru dan siswa dalam pembelajaran menulis paragraf Bahasa Indonesia. Data hasil temuan peneliti mengenai peningkatan aktivitas guru dan siswa berdasarkan jumlah skor yang dicapai akan disajikan dalam gambar 1 .

Peningkatan aktivitas guru dapat dilihat dari kegiatan pendahuluan saat guru menyampaikan apersepsi, tujuan pembelajaran, dan saat guru memotivasi siswa. Kedua peningkatan juga terlihat pada kegiatan inti saat guru menjelaskan tahapan menulis teks narasi dengan bantuan media video teks narasi untuk membuat kerangka teks, beserta tahaptahapnya. Kemudian kegiatan yang terakhir adalah penutup, merupakan kegiatan guru dalam menyimpulkan kegiatan pembelajaran yang telah dilaksanakan bersama siswa dan tindak lanjut dari pembelajaran berikutnya. Jumlah nilai yang didapat dari 80 meningkat menjadi 87,5 . 


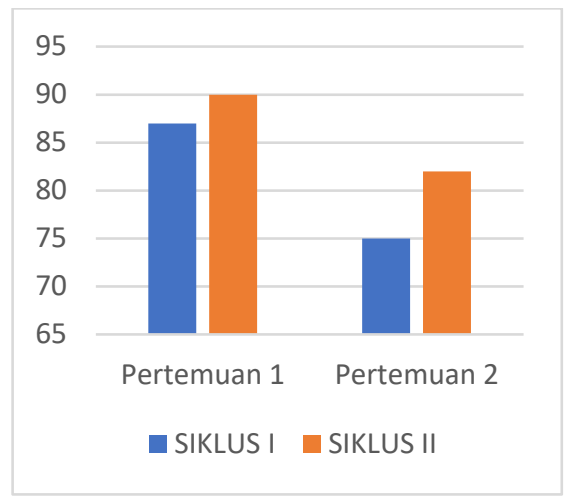

\section{Gambar 1. Hasil Aktivitas Guru}

Peningkatan aktivitas siswa terbukti meningkat mulai dari siklus I ke siklus II yang diukur lewat tiap-tiap tahapan dari penerapan media video teks narasi yang telah dilaksanakan siswa. Dilihat dari siswa menyimak video teks narasi, lalu dilanjutkan pada tahap pra menulis peningkatan terjadi yaitu siswa lebih mudah dalam membuat kerangka teks narasi yang meliputi ide pokok, urutan peristiwa latar tempat dan waktu serta penokohan secara berkelompok. Kedua yaitu tahap Drafting (pembuatan draf) siswa dengan mudah dalam menentukan ide pokok dan meringkas sebagian teks sesuai penulisan yang baik tanpa bertanya pada guru lagi.

Peningkatan juga terlihat dari tahap ketiga yaitu tahap write (menulis) siswa secara mandiri dengan mudah menuliskan hasil ringkasan sesuai catatan kecil yang telah dibahas dengan kelompok pada tahap sebelumnya. Keempat tahap revisi ditandai siswa lebih mudah mengoreksi dan memberikan hasil catatannya pada pengkoreksiannya, siswa kondusif dan patuh terhadap perintah guru. Kelima yaitu pengeditan dimana siswa dalam kondisi tidak ramai karena fokus dengan perbaikan dari hasil tulisan yang telah dikoreksi temannya. Yang terakhir adalah tahap pemublikasian, terlihat siswa berani, percaya diri, dan lantang dalam mempublikasikan hasil tulisannya. Terlihat kenaikan nilai dari 80 menjadi 85,2 di siklus II. Berdasarkan jumlah skor yang dicapai akan disajikan dalam gambar 2.

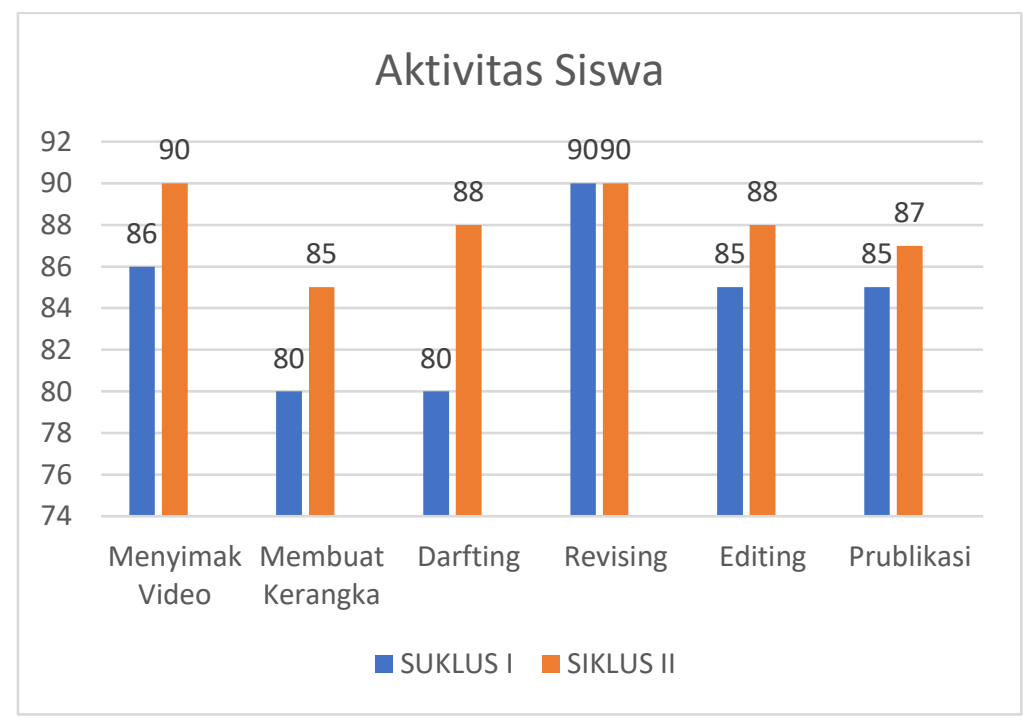

Gambar 2. Diagram Aktivitas Siswa 
Dengan demikian peningkatan aktivitas guru dan siswa dari siklus I ke siklus II dapat dilihat pada gambar 3. Diagram batang warna biru menunjukkan nilai rata-rata aktivitas guru dan siswa pada siklus I dan diagram batang warna merah menunjukkan nilai rata-rata aktivitas guru dan siswa pada siklus II. Terlihat pada grafik aktivitas guru pada siklus I dengan rata-rata 87,5 meningkat menjadi 97 pada siklus II. Selanjutnya, aktivitas siswa meningkat dengan nilai rata-rata 80 menjadi 85,2 pada siklus II. Sehingga dapat disimpulkan bahwa penerapan media video teks narasi dapat meningkatkan kegiatan pembelajaran dan hasil menulis paragraf Bahasa Indonesia pada siswa Kelas V SDN Sukolilo Jabung.

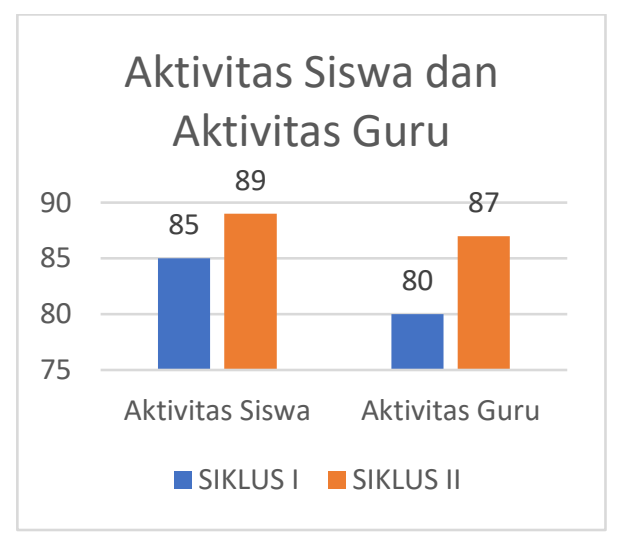

\section{Gambar 3. Hasil Aktivitas Guru dan Siswa Siklus I dan Siklus II}

Dengan penerapan media video teks narasi pada pembelajaran, terjadi peningkatan pada keterampilan menulis paragraf oleh siswa Kelas V SDN Sukolilo Jabung. Proses pembelajaran dengan cara mengelompokkan siswa, saling bekerja sama dalam menentukan ide pokok, menentukan kalimat, meringkas dan menuliskan paragraf dengan memperhatikan penggunaan tanda baca (kosakata, ejaan, dan huruf kapital), tatanan paragraf dan unsur pengembangan paragraf hingga mempresentasikan hasil tulisannya membuat pembelajaran lebih aktif serta berbeda dari sebelumnya. Hal ini terbukti dengan meningkatnya nilai rata-rata dari 71 pada siklus I dan meningkat menjadi 84,63 pada siklus II.

Berikut akan dipaparkan perbandingan hasil keterampilan menulis paragraf Bahasa Indonesia melalui penerapan media video teks narasi pada siklus I dan siklus II dalam gambar 4.

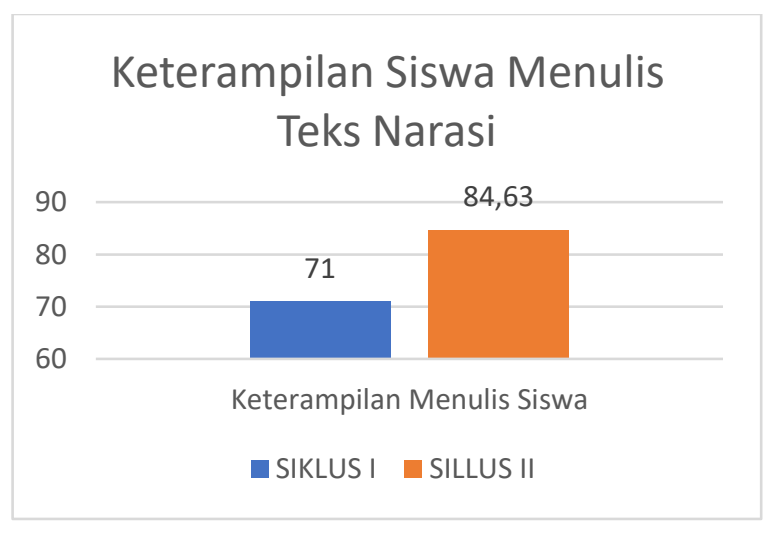

Gambar 4. Hasil Keterampilan Menulis Siswa 
Diagram batang warna hijau menunjukkan nilai rata-rata keterampilan menulis paragraf Bahasa Indonesia oleh siswa yang mengalami peningkatan dari siklus I ke siklus II. Pada siklus I diperoleh nilai rata-rata 73 dan meningkat pada siklus II yaitu menjadi nilai rata-rata 84 yang termasuk dalam kategori baik dan telah mencapai ketuntasan klasikal.

\section{Simpulan}

Penerapan video narasi sejarah dalam pembelajaran dapat meningkatkan keterampilan siswa menulis teks narasi yang didalamnya terdapat peningkatan keterampilan siswa dalam menentukan urutan peristiwa, tokoh dalam peristiwa, ketepatan ejaan, kepaduan kata/kalimat, ketepatan penggunaan bahasa dan huruf kapital, serta penggunaan tanda baca. Aspek keterampilan menulis yang digunakan tersebut agar dapat membuat teks narasi dengan utuh dan benar, sehingga nilai yang dicapai siswa dapat mengalami peningkatan. Peningkatan tersebut dapat dilihat pada siklus I dengan rata-rata 71,2 dengan ketuntasan $72 \%$ dan siklus II meningkat menjadi 84,6 dengan ketuntasan 94\%.

\section{Daftar Rujukan}

Guntur, T. H. (2008). Menulis Sebagai Suatu Keterampilan Berbahasa. Edisi revisi. Angkasa: Bandung.

Badawi, A. (2017). Kemampuan Berbahasa Indonesia Dalam Menulis Deskripsi Berbasis Kurikulum 2013 Pada Siswa SD. Sekolah Dasar: Kajian Teori dan Praktik Pendidikan, 25(2), 121-126.

Rumidjan. (2014). Dasar Keilmuan Bahasa Indonesia Sekolah Dasar. Malang: Universitas Negeri Malang.

Yunus, M. (2014). Hakikat Menulis. Modul 1. Tangerang: Universitas Terbuka.

Zainurrahman, Z. (2016). Peran Pikiran Bawah Sadar (Subconscious Mind) dalam Proses Menulis dan Pembelajaran Naratif. Jurnal Ilmiah Kebahasaan dan Kesastraan, 4(1) 44-48. 